\title{
EFFICIENCY ASSESSMENT OF POSTERIOR WATERPROOFING SYSTEMS OF RENOVATED POROUS LIMESTONE MASONRY WORK
}

\author{
Annamária Dudás, Anita Terjék
}

Original scientific paper Buildings in need of renovation also show typical substructural damages due to aged waterproofing. An often used reconstruction method against capillary rising damp is chemical penetration of masonry walls through injection boreholes, but the efficiency of this technology depends on the material of the wall. Surface coating and renovation plaster give additional moisture protection and together with the chemical injection based horizontal waterproofing provide a complete solution system. Analysis of posterior waterproofing of the soft limestone, a widespread building material of the previous centuries, is required due to its high porosity. In this paper, based on the results of the measurements of an insulated soft limestone masonry building, the effectiveness of the waterproofing system has been evaluated. The measured humidity data also gave opportunity to further research, so thermal and hygrothermal analysis and building-physical comparisons have been performed.

Keywords: chemical injection; energy efficiency; hygrothermal behaviour; limestone masonry; reconstruction; renovation plaster; rising damp

Procjena učinkovitosti posteriornih vodootpornih sustava renovirane građevine od poroznog vapnenca

Izvorni znanstveni članak

Zgrade kojima je potrebna obnova također pokazuju tipična oštećenja temelja zbog zastarjelog vodootpornog sustava. Često primijenjena metoda rekonstrukcije protiv vlage nastale kapilarnim prodiranjem podzemne vode je zaštita zidova zgrade uštrcavanjem kemijskih sredstava, ali učinkovitost te tehnologije ovisi o materijalu zida. Premazivanje površine i žbuka pružaju dodatnu zaštitu od vlage te uz horizontalnu zaštitu od vode uštrcavanjem kemijskih sredstava predstavljaju potpuno rješenje sustava zaštite. Analiza posteriornog vodootpornog sustava u mekanom vapnencu, široko korištenom građevinskom materijalu prethodnih stoljeća, potrebna je zbog njegove velike poroznosti. U ovom je radu, zasnovanom na rezultatima mjerenja izolirane građevine od mekog vapnenca, provjerena učinkovitost vodootpornog sustava. Rezultati izmjerene vlage također su omogućili dalje istraživanje te je izvršena termalna i higrotermalna analiza i graditeljsko-fizičke usporedbe.

Ključne riječi: energetska učinkovitost; higrotermalno ponašanje; rastuća vlaga; rekonstrukcija; ubrizgavanje kemijskih sredstava; zidanje vapnencom; žbuka za obnovu

\section{Introduction}

Walls and floor sections in contact with the ground are deteriorated in most buildings to be reconstructed, which is a result of insufficient waterproofing. The combined or sole effects of aging and the inappropriate application of waterproofing together with the construction defects or changes during the lifetime of a building often cause the damage in building structures. Heating energy consumption of a building with old structure may be multiple compared to consumption of recent/modern facilities, which can also be a consequence of the higher thermal conductivity values in wet building structures. Energy consumption of construction and operation of buildings is $40 \%$ of the total energy consumption $[1,2]$. Since the total building stock replacement rate is less than $1 \%$ in Hungary, reconstruction should be a high priority in construction

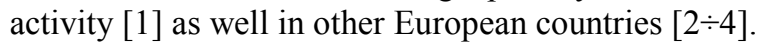

Improving energy efficiency of the existing buildings via reconstruction rather than demolishing them and building new ones is part of the global effort in order to reach sustainable development. Design of low energy buildings is a top priority of the European Construction Strategy, which is also to be met through building renovations. Renovation increases the estimated economic lifetime of a building, furthermore heating energy saving reduces $\mathrm{CO}_{2}$ emissions [2, 3]. Moisture protection and energy development of buildings have not only economic and environmental benefits, but also greatly improve health and living conditions of residents and users as well. Considering that people spend most time of their lives in buildings, it is particularly important to ensure a healthy environment. The World Health Organization defines health protection in its founding document, as a cooperative, coordinated activity limited not only to healthcare, but also as an institutional task, which includes health protection and health education as well. One form of such social and community practice is to improve technical conditions providing a healthy living, moisture free and mould free, hygienic environment [5]. The ratified Hungarian Decree on National Urban planning and Building Requirements (OTÉK) emphasized that constructional structures and premises must be maintained that environmental hygiene and the health of intended users are not jeopardized, and harmful moisture formation and persistency should be prevented.

\subsection{Necessity of moisture protection renovation}

In Hungary the largest proportion of heat losses among residential buildings can be detected in case of family homes and in the so-called tenements of historic quarters of the cities. It should be also noted, that $9 \%$ of family houses and $5,4 \%$ of the urban tenements were built before 1945 [1]. The estimated average lifetime of a solid brick masonry building is $150 \div 200$ years, and of a stone masonry building is about $100 \div 200$ years. Loadbearing structures of these buildings are usually suitable or can be strengthened, but their thermal insulation performance is far below the requirements. Reduced functionality of the traditional waterproofing solutions is representing more challenging problems concerning preservation. Current literature indicates that the 
estimated average lifetime of sealing and waterproofing is $15 \div 30$ years $[1,6]$. Given that $90 \%$ of the buildings in Hungary were built before 1989 , the estimated life cycle of waterproofing has expired, and the majority of buildings are in need of renovation in terms of waterproofing. In buildings from before 1945 only horizontal wall insulation was installed, floor layers or structures under the first residential floor did not get any insulation.

According to a textbook published in 1940 [7] and used for education in the technical university the following waterproofing materials and technologies were available at the time:

Bitumen and tar products: bitumen, asphalt, tar, pitch, bitumen solutions - emulsions, and so-called paper sheets saturated with tar bitumen, fabric insulation boards (The textbook refers to the German-language literature, which reported that adhesive waterproofing using bituminous blank sheets was first produced and used in Hungary in 1895 at the construction of the underground railroad in Budapest.);

- Non-bituminous sealing materials: metal sheet, natural slate paving, solid natural stone, such as Granite, Marble;

Cement insulation: Cement mortar, concrete, sealants for increasing water-tightness.

In case of buildings constructed before 1945, the above mentioned waterproofing materials should have suffered a large degree of deterioration during at least 70 years of lifetime. The insufficient insulation capacity of these materials is basically due to the aging of the materials or the bearing layer, or both, this resulting in the loss of insulation performance, as well as to the damage in tracing of insulation established in the building. Another cause of damage may be the break of insulation due to uneven subsidence of the building, or insufficient tracing of insulation in vertical waterproofing on skirting wall due to the raising of the surrounding terrain level, as well as post-transfer connection of public utility.

This article specifically focuses on solutions of buildings older than 70 years, with no existing, or no properly functioning insulation under masonry, with special emphasis given to the structure with coarse soft limestone masonry.

\subsection{Use of coarse limestone in construction}

In Europe and North America using limestone as building stone was especially popular from the beginning of the $19^{\text {th }}$ century to the middle of the $20^{\text {th }}$ century. High priority public buildings were built using limestone, however in regions close to the mines it was also a favourable material of small-scale buildings. Coarse limestone from the Buda region was one of the most commonly used building material during the Hungarian Millennium, a time for intensive development of Budapest at the turn of the century. Limestone was used in high proportion as structural material in districts (Budafok) and in surrounding villages (Biatorbágy, Sóskút) south of the capital. In the city centre not only in residential buildings, but also in many public buildings (now under architectural heritage protection) blocks from coarse limestone were used in masonry or coverings (i.e. Parliament, Technical University, Basilica, Opera, etc.) [8].

In the regions of Buda Hill types of the rough limestone are named according to their location. Although all of them are of marine origin, relatively light rocks, the varieties slightly differ in material properties. The most common version is the so called ooid limestone, which contains rounded particles. Another common version is the "Sarmatian" limestone, which includes shell fragments formed in the Miocene age in distinct forms (Fig. 1)

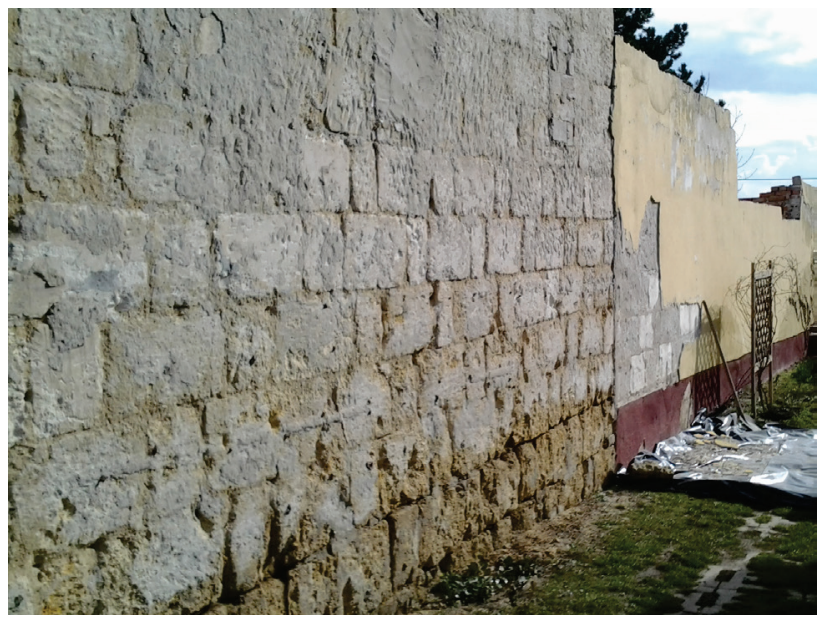

Figure 1 Moisture damaged coarse soft limestone masonry wall

Sarmatian limestone has sometimes up to $37 \%$ porosity, which is a high extreme among coarse limestone types, but the porosity depends not only on location and type, but also the depth of the originating mining layer. Some mining layers yield stones with higher strength and lower porosity [8]. Coarse limestone was a popular building material for its good workability and its relatively low weight. Quarried stone blocks were shaped by high accuracy sawing. In masonry construction calcic, earthy mortar was used.

Due to its high porosity, water absorption of soft limestone is relatively higher compared to other types of limestone. The porous soft limestone of Sóskút (Hungary) shows $16,41 \mathrm{~m} / \mathrm{m} \%$ maximum water content and 1,64 $\mathrm{g} / \mathrm{cm}^{3}$ average density, according to related research [9].

Environmental effects and added moisture can lead to different weathering processes of coarse limestone, which can appear in several forms and can be driven by different chemical reactions. The process can result in black spherical or flat, as well as white weathering crusts, furthermore blistering and alveolar weathering. During the weathering process a new secondary layer is developing on the surface of porous limestone containing calcite and gypsum which gradually leads to decreased porosity and water permeability [8]. As a consequence, wetting rate affected by capillary water absorption is a time-varying process in buildings with coarse limestone masonry. The increase in moisture content of masonry is caused both by the retention of the amount of salt delivered with soil moisture after evaporation near the surface and the change of porosity due to the aforementioned weathering. Limited evaporation on the wall structure raises the height of wet section, so the rate of damage increases. 


\subsection{Purpose of testing posterior waterproofing}

Tests and results presented in the article are used to evaluate the efficiency of posterior waterproofing technology, as well as to measure how waterproofing affected the physical specifications of the building structure. Moisture protection efficiency of the posterior waterproofing is shown by measuring the moisture content of masonry, and comparing its original and restored state. Based on the measurements further thermal and hygrothermal calculations have been carried out to show what level of efficiency could be achieved by decreasing moisture content and by the complex restoration.

\section{Tasks in reconstruction of moisture protection}

The aim of building restoration is preservation and to prevent or terminate obsolescence. Physical degradation concerns structural and/or geometric damage of the building material, while obsolescence implies to functional failure. Physical degradation often occurs due to building-physical processes, which leads to obsolescence, so the material does not function properly. Accordingly, damages caused by wetting can be defined as building-physical obsolescence, so time-varying adverse change of building-physical performance occurs [1].

Reconstruction with thermal insulation and with window replacement takes place in a growing number. Typically large housing estates, block of flats, but also small scale family houses are reconstructed. Diagnostic studies prior to technological steps of the construction are always necessary, but not always carried out, despite the fact that restoration aiming to improve thermal insulation is recommended starting with determination of moisture content. Building diagnostics allows assessment of the condition of the existing waterproofing, then based on its results, subsequent restoration of waterproofing and facilitation of motion of harmful moisture can be designed. Improvement of the existing waterproofing system or its replacement with a new one can greatly affect the overall usability of the building, the comfort level, the heat capacity and also the lifetime. Surplus moisture and salinity content present in the structure will determine which restoration method can be applied efficiently.

Thus, in the case of underground building structures testing of moisture content should precede those technological steps providing heat loss savings. Design of required waterproofing solution is supposed to be based on test results. The posterior waterproofing treatments should cut moisture supply and then also facilitate drying.

\subsection{Moisture in building structure and its effects}

Damages due to moisture in building structure are the results of water absorption in liquid state and diffusion processes. The liquid-state water absorption is the dampening effect of being in contact with the ground, or it occurs because of seepage or subsoil water pressure. In structures these cause absorption of water by capillarity, resulting from junction or under pressure. Moisture transport in gaseous state is another form how water can gain access into the structure. Then, through the process of vapour diffusion water vapour absorbed from air gets into the pores of the structure. Another frequent cause of wetting is condensation below the dew point temperature. This phenomenon is known in thermal bridging connections, but it can also cause damage on the surface of the basement structures at low temperature [10 $\div 12]$.

Moisture absorption of surface elements causes fragmentation and weathering of materials, typically as a result of tensional effect of ice lenses due to the alternating freeze-thaw cycle. In case of capillary water absorption damaging process increases because of the amount of delivered salt remaining after evaporation. The hygroscopic water absorption of salt crystals enhances the moisture content of the structure, prevents drying, and the growth in volume caused by crystal formation often forces dropping of the plaster layer.

\subsection{Examination of posterior restoration and waterproofing systems}

The facilitation of departing moisture from the building structures or separation of the wet structure from the inner space can be accomplished by different materials and technologies. The alternative technologies limit capillary rising damp, and also provide solutions against water absorption from ground or precipitation.

Solutions commonly used to prevent capillary water absorption are classified in groups of mechanical (i) electrokinetic (ii) and chemical (iii) methods.

(i) Some of the mechanical solutions are carried out by dismantling, insulating, and rebuilding masonry section by section. Since it can only be done by substitution of the auxiliary structure and with high labour input, it is only preferred in cases where no other solution is available. Moisture supply can also be prevented mechanically by cutting wall, sawing, and placing PVC insulation plate or steel plate into the gap. A similar solution for posterior waterproofing is the dynamic insertion of relief-stiffened steel plates. In this case impacts on structure may damage the sensitive structural parts.

(ii) In electrokinetic methods moisture content can be reduced in porous materials by taking away moisture.

(iii) From a technological point of view, a less complicated solution than the above mentioned is offered by chemical injection. In this method a moisture barrier layer is formed by the effect of a chemical substance put into drill holes in the cross-section of the wall. This solution is examinated in detail in the article, along with the necessary additional structural treatments. The injection is completed by the application of surface insulation coatings and a renovation plaster system with high volume of entrained air.

\subsubsection{Renovation plaster system}

Requirement of smooth wall surface needs construction of a plaster layer during the renovation of traditional masonry structures. Using traditional plaster layers would close the path of the vapour exiting from the 
structure according to their vapour diffusion coefficient. The appropriate solution is using restoring renovation plasters, which with their large pore diameter and porosity are capable to facilitate drying of walls and to store salt delivered. The moisture supply, the salt content transported in the moisture, the diameter of pores of the used renovation plaster and the porosity of it all influence the lifetime of the renovation plaster system [13].

The restoration plasters contain hydrophobic components in order to limit water absorption and to be more resistant to water and salt crystallization [14, 15]. Using renovation plasters facilitates moisture removal by drying and increases service life of subsequent restoration layers. It should be noted though, that the restoration plaster system does not provide posterior moisture protection, so moisture content of the structures can only be reduced permanently if moisture supply is terminated. In addition, retention of the amount of salt delivered by capillary rising is continuously saturating the pores of restoration plaster layer, thus reducing its lifetime.

\subsubsection{Insulation coating}

Flexible insulation coatings, which can be applied on imperfect surfaces of an existing building, provide solution for the implementing difficulties of building reconstruction. In terms of waterproofing performance the necessary specific material volume to be used is given by the manufacturer's specifications. Some insulation coatings provide layers resistant up to 10 bar water pressure. Vapour diffusion capacity of insulation coatings is usually significantly higher compared to bituminous and plastic-based waterproofing, so moisture enclosed in the structure by renovation could dry up in long term.

Insulation coating can primarily provide protection for the external skirting wall against water from precipitation and water bounding from the facades or from the ground. Secondly, it can give surface protection inside by connecting damaged or missing floor or wall insulation. Capillary rising in the cross-sections of the walls is not obstructed even with this solution, thus using of restoration plaster system is necessary.

\subsubsection{Chemical injection}

In this case cross-sectional injection of the wall creates a moisture barrier layer, and cut moisture delivering capillaries. The chemical (such as alkaline silicate, siloxane, silane, etc.) with hydrophobic and occasionally with further capillary tightening effects and substances, can be ingested through the injection holes under low pressure or even without pressure and forms a continuous moisture barrier [16, 17, 22]. Restoration of load-bearing capacity of masonry can be achieved with high strength mortar put into the weakening holes following the injection. An "in-situ" testing method could show an approximated linear relationship between the strength of the materials of the wall and the penetration speed of the drilling machine [18]. Arranging holes in several lines and applying filling mortar with also hydrophobic properties can increase the efficiency of the water barrier layer.
The injected waterproofing provides protection against capillary moisture, but supply surface protection only in the injection zone, in other areas the surface of the structure remains unprotected against moisture load. Mass injection shall be applied if linear injection is not sufficient, due to change in direction, altitude plane or structural connections of the wall. In doing so, holes are drilled evenly distributed in a reticulated way on the whole surface of the wall, and this way a continuous watertight block is created. Because of its high cost and high labour demand this technology is rarely applied.

\subsubsection{Combined waterproofing solution}

Moisture protection reaches its maximum efficiency by combined application of methods listed above. Protection against moisture and water is provided by injection in the cross-section of the wall and insulation coating on its surface. Continuous lining of the waterproofing system is crucial concerning the efficiency of the complex system of moisture protection. Also, the height of the injection line in the structure should be as low as possible, then surface protection should be adjusted to it. This will reduce the proportion of structural parts loaded with moisture after restoration.

\section{Examination of the effectiveness of posterior waterproofing on an experimented building}

The presented posterior waterproofing solutions can be generally applied in building structures from porous building materials, especially in masonry buildings with load-bearing structure. In buildings with coarse limestone masonry, because of the high porosity, the saturation degree of chemical injection and thus its effectiveness was unknown. In our research evaluation of the combined posterior waterproofing system was done based on diagnostics of performed works on an example building.

\subsection{The building and the methods of its posterior waterproofing}

The subject of the measurements and the calculations was a building with coarse limestone load-bearing masonry of unknown age, but certainly built before 1945 (Fig. 1). As part of the renovation, posterior waterproofing was carried out before the building-energy restoration works.

The original residential building was likely to be built above and around a pre-existing basement on the site, also with coarse limestone masonry. During the present reconstruction and modernization two rooms had been attached to the existing building by keeping, strengthening major supporting structures. As reconstruction started it was discovered that the limestone ground layer with high load-bearing capacity is close to the surface, so the stone foundation of main walls on the ground floor are independent from the basement walls and their foundations (see later Fig. 5).

The load-bearing walls on the ground floor were made typically from $50 \mathrm{~cm}$ thick coarse limestone blocks with binding calcic-earthy mortar. During surveys prior to the actual construction work, dampness and mould growth 
were observed on the wall structure up to 0,8 to $1,0 \mathrm{~m}$ high. Festering of the original wooden strip floor indicated the lack of insulation under the floor, which was confirmed later. In masonry in the line of the floor remaining fragments of paper sheets saturated with tar showed the insufficiency of the waterproofing.

The north facade of the building is on the property line connecting to the street and the natural slope of ground is around $2 \%$ in the north-south direction. Thus, the street facade and the upper section of the west facade act as a barrier to the surface rainwater runoff. The northwest corner of the building is the most exposed to the impact of rainfall and driving rain too, since it is facing the prevailing wind direction of the Central Hungarian region.

The moisture content of masonry was measured half a year after the formation of the posterior injection waterproofing. The reconstruction works of moisture protection were made step by step after injection. The floor structure was rebuilt with a layer of impermeable reinforced concrete on compressed gravel bedding, however the waterproofing connection with cement based slurry insulation coating was completed only about two months later. The renovation plaster system was in different state of readiness on each facade, some parts with relatively fresh plaster.

Access to the outer walls of the basement for applying waterproof covering was not possible, given that it is located in a smaller area under the building. In order to achieve complete waterproofing mass injection would have been the only solution, but at this scale it is not economical, so a sole renovation plaster system was chosen for the reconstruction of the basement wall. The upper third of the south basement wall was injected in two lines because of the plane change between stairs and floor.

\subsection{Method of moisture measurement}

On-site measurements were carried out by using BHX40 protimeter, a portable moisture meter. The sample metering was taken with deep wall probes measuring in 8 and $25 \mathrm{~cm}$ deep holes at $0,25 \mathrm{~m}$ and 0,75 $\mathrm{m}$ height in masonry. Further measurements were made under the injection level approximately $20 \mathrm{~cm}$ deep beneath the floor. The central axis of the injection was 15 $\mathrm{cm}$ over the upper plane of the concrete base.

The applied instrument works with the method of measuring the electrical conductivity of masonry. Moisture content in individual holes is given in the value of WME (wood moisture equivalent), since the tool was originally developed to measure wood dryness. The principle of measurement is that electrical resistance of wood varies depending on its moisture content. The greater is the specific electrical resistance of timber blocking DC, the lower is the water content. [19] The obtained WME results were converted using guidelines for various testing elements from different materials prepared by the manufacturers of the device [20].

Temperature and relative humidity values were recorded repeatedly during examination by Testoterm 6010 temperature and humidity measuring device: the recorded averages were the following: in the building the average $T_{i}=+13,7^{\circ} \mathrm{C}, \varphi_{i}=82 \%$; outdoors $T_{e}=$ $+11,30{ }^{\circ} \mathrm{C}, \varphi_{e}=88 \%$; in the basement $T_{c}=+12,5^{\circ} \mathrm{C}, \varphi_{c}=$ $92 \%$. The positions of the cross-section of drilling are shown in Fig. 2. The monitoring holes were drilled using a bit of $10 \mathrm{~mm}$ in diameter, so deep wall probes could fit in.

Given that the construction was in progress during measuring, several cross-sectional measurements planned previously could not be performed. In order to have a complete number of cross-sectional results, these measurements were replaced by laboratory tests. Additional samples were also taken for laboratory testing in order to verify the measured results. Moisture content of the powdered samples from the holes was determined in standard ÉMISZ 340:1999 [21] conditions as the difference between wet and dry mass after drying in laboratory oven. Drill holes of the control samples for laboratory testing were located horizontally $5 \div 10 \mathrm{~cm}$ away from the position of measurements with the protimeter, this way drying through the holes drilled for the protimeter could not influence the moisture content values of the samples between the two tests (in 3 days). During this period, boundary conditions remained the same.

\subsection{Evaluation of test results}

The measurements and laboratory test results are summarized in Fig. 3 regional distribution and proportions are shown.

There is only negligible difference between laboratory results of comparative control sampling and on-site testing results. For two samples with low moisture content the difference was $1 \%$ and $4 \%$. On one spot with around the average moisture content the difference was large, however drill hole powder showed brick wall panel replacement in that section, so this result had to be excluded. Since all other control samples gave the same results, the ones measured with protimeter are considered to be reliable.

Based on 97 measurements made by the protimeter and five additional laboratory tests moisture distribution of masonry around skirting level could be mapped. The efficiency of the injected waterproofing could be measured by the evaluation of the results. Measurements under injection zone showed mostly full saturation, while moisture content was gradually decreased vertically above injection as it was expected.

Measurements taken inside under the injection level showed full saturation or very wet state. Outside measurements taken near the ground and values coming from the basement also showed full saturated state in even greater proportion. The maximum value measured by protimeter was $60 \% \mathrm{WME}$, which is outstandingly high, since according to the conversion table a sample with above $20 \%$ WME should be evaluated as wet, while WME value below $16 \%$ considered to be dry.

In case of rocks the conversion recommended a maximum of $5,5 \mathrm{~m} / \mathrm{m} \%$, which is assigned to $26 \% \mathrm{WME}$ value [20]. Since the saturated water content of soft limestone is tested $16,41 \mathrm{~m} / \mathrm{m} \%$ [9], the measured values at more than $26 \%$ WME have been calculated scaling to the saturated moisture content above. 
Further testing of the research proved that the area under the injection zone can be assumed being in saturated state for many reasons. On the one hand, the length of the inclined drilling through the layers of the floor did not ensure the uniformity of measurements; on the other hand, in the cross-section of holes in the basement, measures taken in the wall with direct contact to the soil mostly indicated maximum values.

It can be assumed that in some positions the measurement holes were drilled directly into or just right under the injected area, so results were significantly lower compared to the moisture content expected according to the surrounding measurements. These results can be explained with the fact that injection material had spread further into the cross-sectional area than it was planned due to the high porosity of coarse limestone and the low strength, high porosity nature of mortar. This theory is supported by the fact that during injection holes had to be refilled several times. More alkali silicate material was injected into the wall than the required $15 \mathrm{litre} / \mathrm{m}^{2}$ per cross-section [22]. In fact, according to the technical rules of construction, injection should be continued until surplus injecting material appears in the next hole. The subsequent refilling of the hole can only show whether the wall is capable of absorbing additional injection material. During repeated refilling smaller amounts can be delivered, thus process of injection can be terminated after multiple saturation.

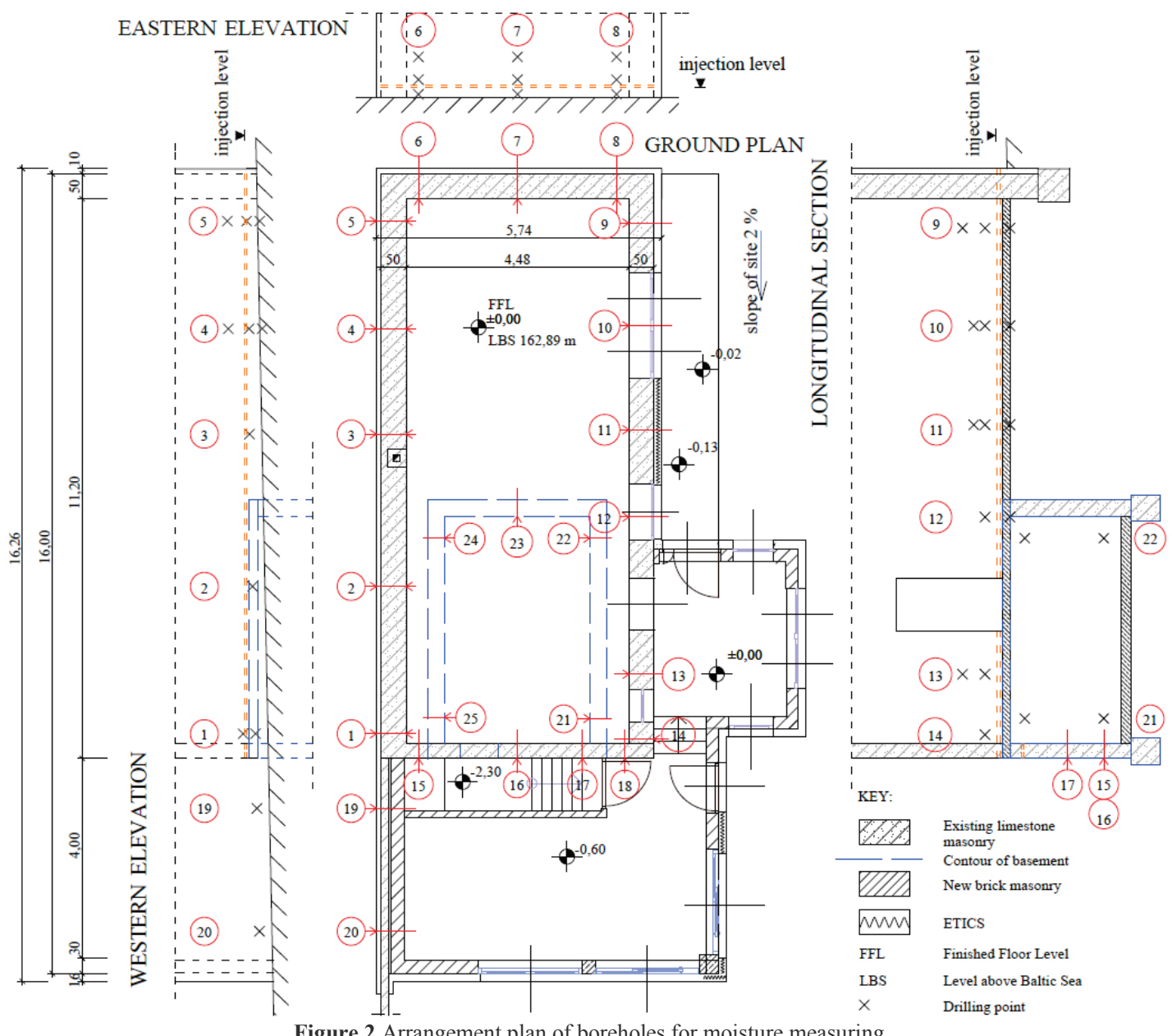

Comparing values measured near the original surface of the wall $\left(m_{1}=8 \mathrm{~cm}\right.$ depth compared to the newly plastered surface) and values measured in the centre line of the original wall $\left(m_{2}=25 \mathrm{~cm}\right.$, and $m_{3}=15 \mathrm{~cm}$ for the $30 \mathrm{~cm}$ thick walls) it can be seen that the average moisture content is definitely higher on the surface. It can be explained by the hygroscopic moisture absorption of residual salt crystals on the surface of the wall, but the reason is more likely the wet technology of rendering. Plastering was performed just in weeks before measurements, which might cause presence of significant moisture. The plastering sequence of the individual masonry walls (western, northern, eastern) also justifies construction moisture as does the nearly same value of moisture content measured in $H=0,25 \mathrm{~m}$ and $H=0,75 \mathrm{~m}$ height, $m_{1}=8 \mathrm{~cm}$ depth (see 1, 2, 6, 7, 8 cross-section of boreholes Fig. 2).

Results measured near the surface on the outer western front wall show significantly higher values than in the centre line of the wall (see Fig. 3). The surface protection waterproofing of the external side of skirting had not been finished before measuring. Therefore water conducting on the surface and reflection of rainwater from directly connected concrete slab (car driver ramp) soaked the surface. Moisture content in the $4^{\text {th }}$ and $5^{\text {th }}$ crosssection was especially high, it reached the saturation level. At this corner of the building growing moisture content was measured even above the injection zone, therefore the necessity of surface insulation coating is obvious. 
There are different ratings for assessment of injection efficiency. The methods compare the measured moisture values to the moisture content of the original/untreated structure or the structures under the insulation level. According to the standard ÉMISZ 340:1999 [21] of the Company for Quality Control and Innovation in Building Construction (ÉMI) the subsequent drying effect is considered to be in an advanced stage, where at least 25 $\%$ reduction is detectable in moisture content compared to the original state. According to the guideline WTA 4-404/D [23], an injection is assessed effective if relative humidity of masonry is decreased by $50 \%$ after 90 days.

Regarding that protimeter sample values under 14 are considered to be dry, and for moisture content under this level coefficients are not available, only the proportions of WME \% values can serve as the basis of comparison (Fig. 4).

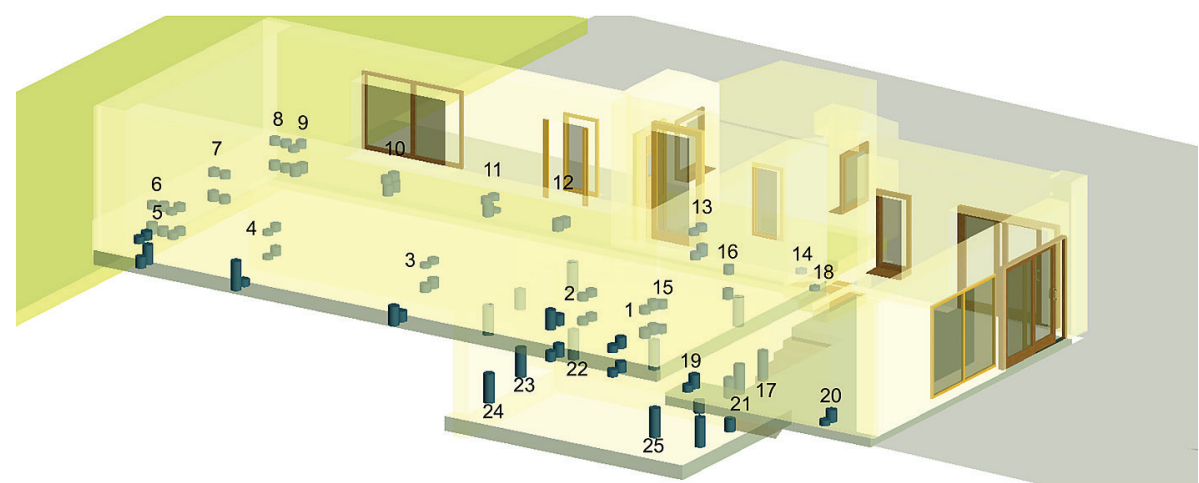

Figure 3 Measured moisture contents represented at positions of boreholes. Mainly saturated values below injection zone are represented only in basement. Numbering belongs to drilling cross-sections according to Fig. 2

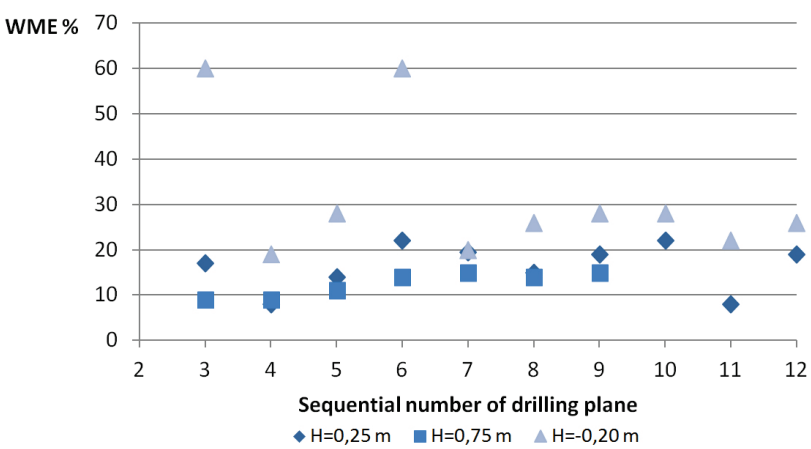

Figure 4 Wood moisture equivalent values measured by protimeter at $3 \div 12$ drilling holes in $m_{2}=0,25 \mathrm{~m}$ depth

For the calculation of waterproofing efficiency crosssectional samples taken at $H=0,25 \mathrm{~m}$ and $H=0,75 \mathrm{~m}$ height and in $m_{2}=0,25 \mathrm{~m}$ depth of the $3 \div 12$ drilling planes were tested, as these planes have similar building structures with similar original moisture load. (Fig. 4)

Comparison was based on the moisture content under injection level, since it can be assumed that due to the high porosity and capillary suction capacity of the wall the original moisture content was similar over the injection. The measured data averages at $H=0,25 \mathrm{~m}$ height showed $43,18 \%$ decrease in WME value, while the same at $H=0,75 \mathrm{~m}$ height showed a $56,08 \%$ improvement on average. Considering that at the time of the research reconstruction was still ongoing, the building was untenanted, drying was limited because of the presence of technological moisture and lack of heating, the injection efficiency ratio is seen as satisfactory, not reaching the WTA requirement but feasible according to standard of ÉMI. On the higher part of masonry the values satisfy both requirements.

\section{Thermal analysis}

Variation in moisture content changes thermal conductivity of building structures. Thermal conductivity increases with growing moisture content, therefore heat flow also increases through the building construction. Posterior waterproofing prevents moisture supply, so drying can be realized. The evaporative drying process depends on many parameters such as room temperature and relative humidity, ventilation airflow, vapour permeability of layers of the building structure, subsurface hygroscopic salt content, etc. All these parameters influence the speed of drying after posterior waterproofing. Drying will be continued until reaching the equilibrium moisture content $\left(\omega_{\mathrm{E}}\right)$ under particular boundary conditions, provided that the supply of moisture is prevented.

The aim of thermal analysis is to quantify heat losses due to moisture content and to assess improvement performed by posterior waterproofing. The analysis was completed with HEAT3 finite element simulation software, with temperature and heat transfer resistance boundary conditions.

\subsection{Base data, boundary conditions}

Base data of thermal analyses are the thermal conductivities of building materials, which in this case was considered as $\lambda=1,1 \mathrm{~W} /(\mathrm{m} \cdot \mathrm{K})$ for coarse soft limestone according to EN 12524:2000 [24] ( $\lambda$ was given to $\rho=1800 \mathrm{~kg} / \mathrm{m}^{3}$ density, a conservative value, since influence of mortar and inhomogeneous construction of masonry wall was ignored). Examination of increase of thermal conductivity related to moisture content was the subject of literature [10, 11], and modified thermal conductivity is usually calculated based on dry characteristic.

$$
\lambda(w)=\lambda_{0} \cdot\left(1+\frac{b \cdot w}{\rho_{\mathrm{s}}}\right),
$$


where: $\lambda(w)$ - thermal conductivity of moist material $(\mathrm{W} /(\mathrm{m} \cdot \mathrm{K})), \lambda_{0}-$ thermal conductivity of dry material $(\mathrm{W} /(\mathrm{m} \cdot \mathrm{K})), b$ - thermal conductivity supplement $(\% / \mathrm{M}$ $\%), \rho_{\mathrm{s}}-$ bulk density of dry material $\left(\mathrm{kg} / \mathrm{m}^{3}\right)[10]$.

The $b$ factor expresses moisture impact in relation to wet weight percentage. For soft coarse limestone factor $b$ is not known, but lime-silicate bricks $\left(\rho=1800 \mathrm{~kg} / \mathrm{m}^{3}\right.$, $\lambda=0,7 \mathrm{~W} /(\mathrm{m} \cdot \mathrm{K}))$ or concrete $\left(\rho=2300 \mathrm{~kg} / \mathrm{m}^{3}, \lambda=1,3\right.$ to $1,5 \mathrm{~W} /(\mathrm{m} \cdot \mathrm{K})) b=8[10]$.

Another approximate method for calculating the value of wet thermal conductivity is based on $n$ factor, which enters moisture content according to a parabolic function graph [11].

$\lambda(w)=\lambda_{0} \cdot\left(1+\frac{n}{100}\right)$

where $n$ is the thermal conductivity supplement (-).

Calculations based on math formulae (2) provide consequently higher thermal conductivity increments, so analyses of the presented research were carried out on the basis of the values obtained by this method. As high porosity of soft coarse limestone enables higher water absorption than the absorption observed in case of other stones generally used for masonries, the increase in thermal conductivity is assumed greater.

The moisture content values were recorded on the basis of measurement results detailed in 3.3 chapter and were averaged for parts of elevations. Form of general drying curve has been taken into account as in the midline cross-sectional data. Wet thermal conductivity values obtained from formula (2) are the base values corresponding to the geometric positions of simulation models.

Temperature boundary conditions of the simulation models were respectively: $+20{ }^{\circ} \mathrm{C}$ indoors, $-2{ }^{\circ} \mathrm{C}$ outdoors (according to later hygrothermal examination), while $+4{ }^{\circ} \mathrm{C}$ in the unheated cellar. The thermal protective role of the surrounding ground had an effect on the examined details. The boundary conditions were stated as $+9{ }^{\circ} \mathrm{C}$ at a depth of 15 meters, which is a steady-state temperature under the natural ground level in Hungary, instead of using thermal conductivity of the soil as base data.

\subsection{Variations of simulation models}

Based on the assessed distribution of the measured moisture (3.3 chapter) and the geometries of the original limestone wall, five typical details were chosen for detailed modelling. As it is visible in Fig. 2 foundation of the northern, eastern and higher western masonry close to the street have no connection to the cellar, so these details have the same structural design. Building construction located in the lower part of western elevation shows a different thermal character due to the ground-cover and to the cellar foundation (Fig. 5). The southern part of the structure is different again, where entrance of the cellar has been added to the interior part with secondary structures, but not heated area (Fig. 6).

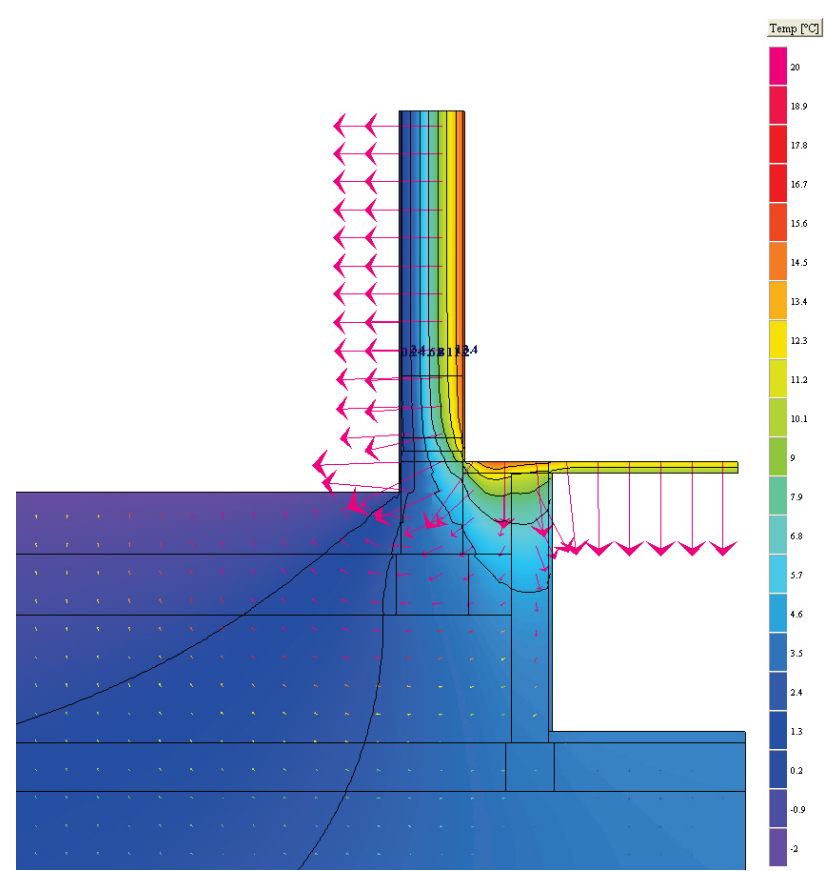

Figure 5 Temperature isotherms of detail at lower part of western elevation; variation $(\mathrm{E})$ : after injection with dry walls without renovation plaster and without thermal insulation

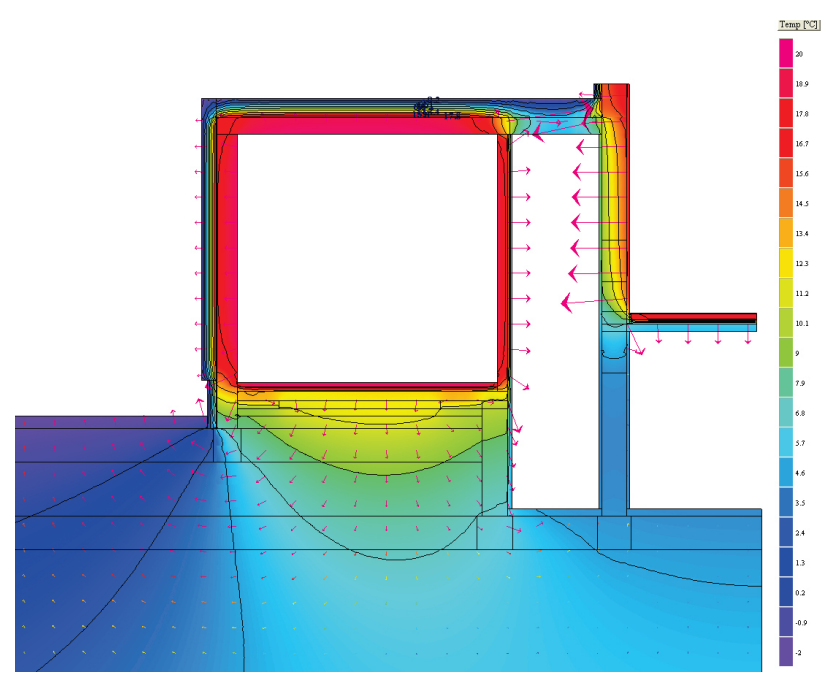

Figure 6 Temperature isotherms of cross-section at southern elevation; variation $(\mathrm{F})$ : after posterior waterproofing system and thermal insulation

Simulation has been carried out for all five mentioned structural designs and assessed for several versions. First of all simulation of the heat losses based on the actual measured results gives an opportunity to make a conclusion. Then, in order to assess the current status in comparison, other versions have also been evaluated. Theoretical models were elaborated for the completely dry state (A) and for the assumed initial moisture distribution prior to the current status (B) as well as for the different versions and combinations of the reconstruction methods. These later ones also demonstrate what thermal improvement can be achieved in various renovation options. Version of the current status (C) represents the situations at the time of the measurements. Regarding the measurement methods it should be noted that in the two cases $H=0,25 \mathrm{~m}$ and $H=0,75 \mathrm{~m}$ over the injection zone, the models were calculated with $\lambda(w)$ thermal conductivity values belonging to the actual 
measured moisture contents, while under the injection zone, considered being in saturated state, models were built with $\lambda(w)=2,585 \mathrm{~W} /(\mathrm{m} \cdot \mathrm{K})$ value. Simulation models were created also for the expected future conditions after implementing further posterior waterproofing elements, in variants with renovation plaster (D) and without that (E). In addition a version (F) of the complete renovation with thermal insulation on the facade was also calculated. For further comparison, the length of the floor layer with actual and with the assumed multiple length for even geothermal isotherms were reported.

Altogether 40 simulation models have been evaluated. Figs. 5 and 6 represent temperature isotherm distribution for two typical simulation models.

\subsection{Simulation results, conclusions}

Impact of moisture on heat losses of the examined details was analysed by subtraction of heat loss referred to the wall from the sum of vertical and horizontal heat losses. In order to reach results independent of various moisture contents of the details, and to measure only the efficiency of waterproofing, heat loss of theoretical dry wall conditions was deducted from the total heat loss in all cases. Thereby the additional heat losses could be obtained, which were caused by moisture content of the wall, by the structural detail of skirting and by the order of layers of the floor, accordingly heat loss differences between the cases can be realized. (Fig. 7)

Figs. 5 and 6 illustrate that the southern and the western details along the basement junction have different structural characteristics. If only details at the north, east and at the upper west are considered, based on the results of the structural and refurbishment cases examined, the following conclusions can be drawn:

A vs. B: The original moist structure prior to reconstruction compared to the theoretical dry structure shows $8,26 \%$ higher rate of heat flow on average for sum of skirting and floor correlated to total heat flow.

$\mathrm{B}$ vs. C: Comparing the original moist case and the measured moisture content results there is $3,34 \%$ difference decrease in the rate correlated to total heat flow.

B vs. E: In case of dry walls above the injection zone which is expected in the future, the simulation shows 3,43 $\%$ improvement in ratio to the total heat flow in skirting and floor areas compared to the original moist state.

C vs. D: Application of renovation plaster system resulted in the reduction of the total heat flow on average of $\Delta Q=12,54 \mathrm{~W}$, which means $9,83 \%$ improvement on average.

D vs. F: As part of the overall reconstruction with completed thermal insulation (ETICS) on facades and skirtings the total heat loss is significantly $(\Delta Q=72,16$ W) reduced (see Fig. 6), while the higher wall heat transfer resistance swings the heat flow in the direction of the skirting. In conclusion the heat flow through the skirting and floor increases by $38,44 \%$ on average relative to the total heat flow. It should be pointed out that thermal insulation of skirting and foundation would have further mitigated total heat losses, and heat flow swing would have been significantly reduced.

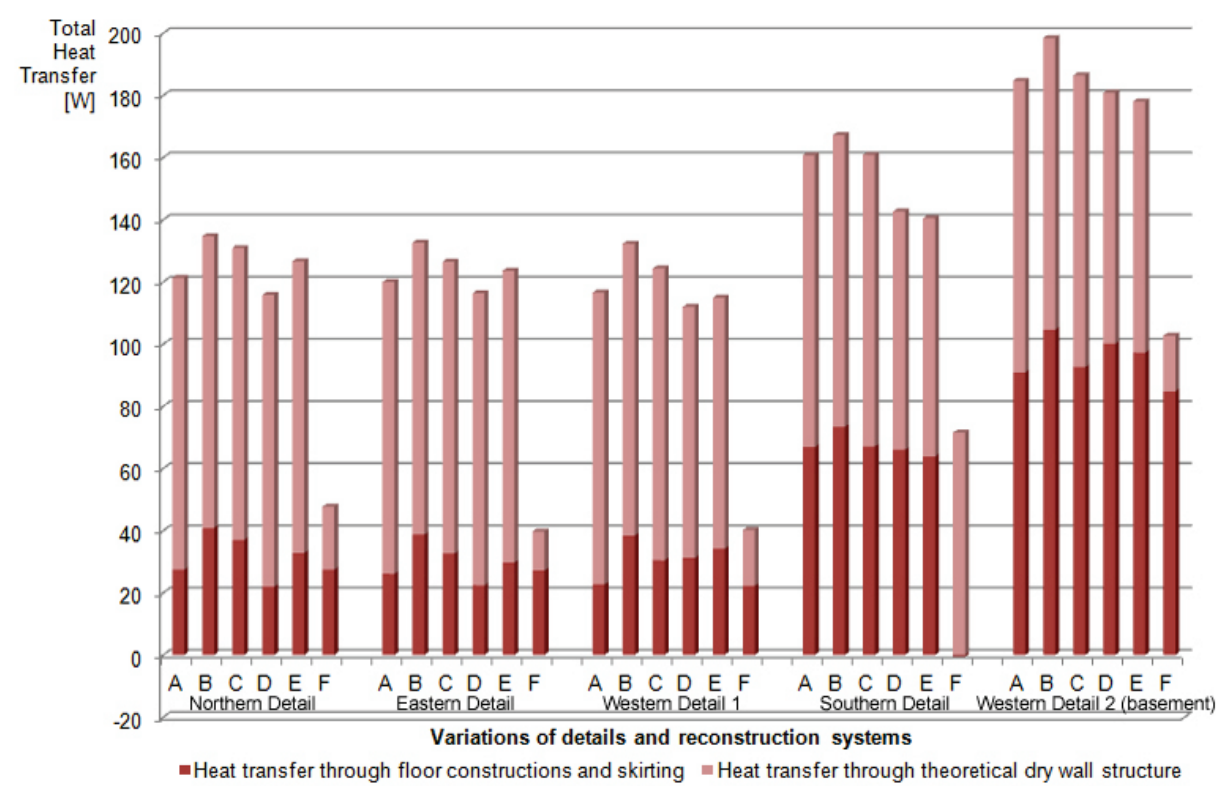

Figure 7 Cumulative heat loss relating to heat losses through the floor and skirting at the examined details in different renovation stages.

* Case $\mathrm{E}$ at north and east elevation represents results without application of renovation plaster

A: Theoretical dry construction: dry foundation and wall structures; B: Moist wall structures: presumed moisture content before waterproofing; C: After the treatment of injected waterproofing based on measured moisture data; D: After the treatment of injected waterproofing based on measured moisture data, renovation plaster; E: Estimated future state: dry walls above injection zone; F: Reconstruction with waterproofing and thermal insulation on walls.

In several cases of the simulation width of the floor was taken as $7 \mathrm{~m}$ to eliminate the effect of temperature distribution changes due to skirting connection to the ground. The different floor length would affect the rate of heat flows of walls and floors. However, in order to assess situation closer to real heat flows of the floors, in case of the detail next to the west ramp two versions were developed, with $7,00 \mathrm{~m}$ and $2,25 \mathrm{~m}$ floor width. The results showed that the cumulative heat loss ratio of skirting and the floor in the two versions differed by less 
than $2,4 \%$ in all but one structural variants, typically 1,5 $\%$ difference was recognized. The case of total reconstruction with thermal insulations formed an exception again.

Summarizing the individual values of the details for the different cases revealed that heat flows of the realized reconstruction with thermal insulations show closely the same values as the theoretical dry structural version. Achieving the exact theoretical values would have only been possible with injected posterior waterproofing for the whole building construction with mass injection.

\section{Hygrothermal analysis}

Choosing between reconstruction technologies, future hygrothermal consequences of the technical solutions should be weighed. Posterior waterproofing prevents structure from further damage caused by newly entering moisture, however the original moisture content of the materials should be fostered to depart.

Hygrothermal calculations were summarized on the layers of retrofitted soft limestone masonry wall. Comparative analysis was made on the following wall structure varieties: the original wall smoothed with traditional cement based plaster (R1), renovation plaster inside on the cleaned wall (R2), the refurbished wall with renovation plaster on both sides (R3), the skirting wall with elastic cement based waterproofing slurry and XPS thermal insulation on outer side (R4).

Standardised hygrothermal examination calculates with one-dimensional vapour flow and constant boundary conditions. The mathematical-physical model calculates vapour flow caused by vapour pressure difference on sides of the structure. Quotient of thickness and vapour diffusion coefficient of a particular building material provide vapour diffusion resistance of a layer. Vapour flow density of the whole order of layer is partitioned in function of the vapour resistances of layers, thus vapour differences of layers set the graph of partial vapour pressure. During examinations diagrams and relationship of partial and saturation vapour pressures are analysed. Presenting the two graphs in scale of the temperature the orders of layers can be evaluated (see Fig. 8). Intersection of the graphs of vapour pressures illustrates a risk of vapour condensation $[25 \div 27]$. Vapour diffusion phenomenon in the reality is rather a time-dependent mechanism with variable boundary conditions, and influenced by numerous parameters, e.g. evaporation, characteristics of outer and inner air, moisture sources, etc. Therefore, a more accurate, combined modelling would give more realistic overall results, however it is extremely complex, and would require dynamical simulation [28]. As the aim of this article is solely to compare reconstruction techniques, for the hygrothermal examination the standardized method was used.

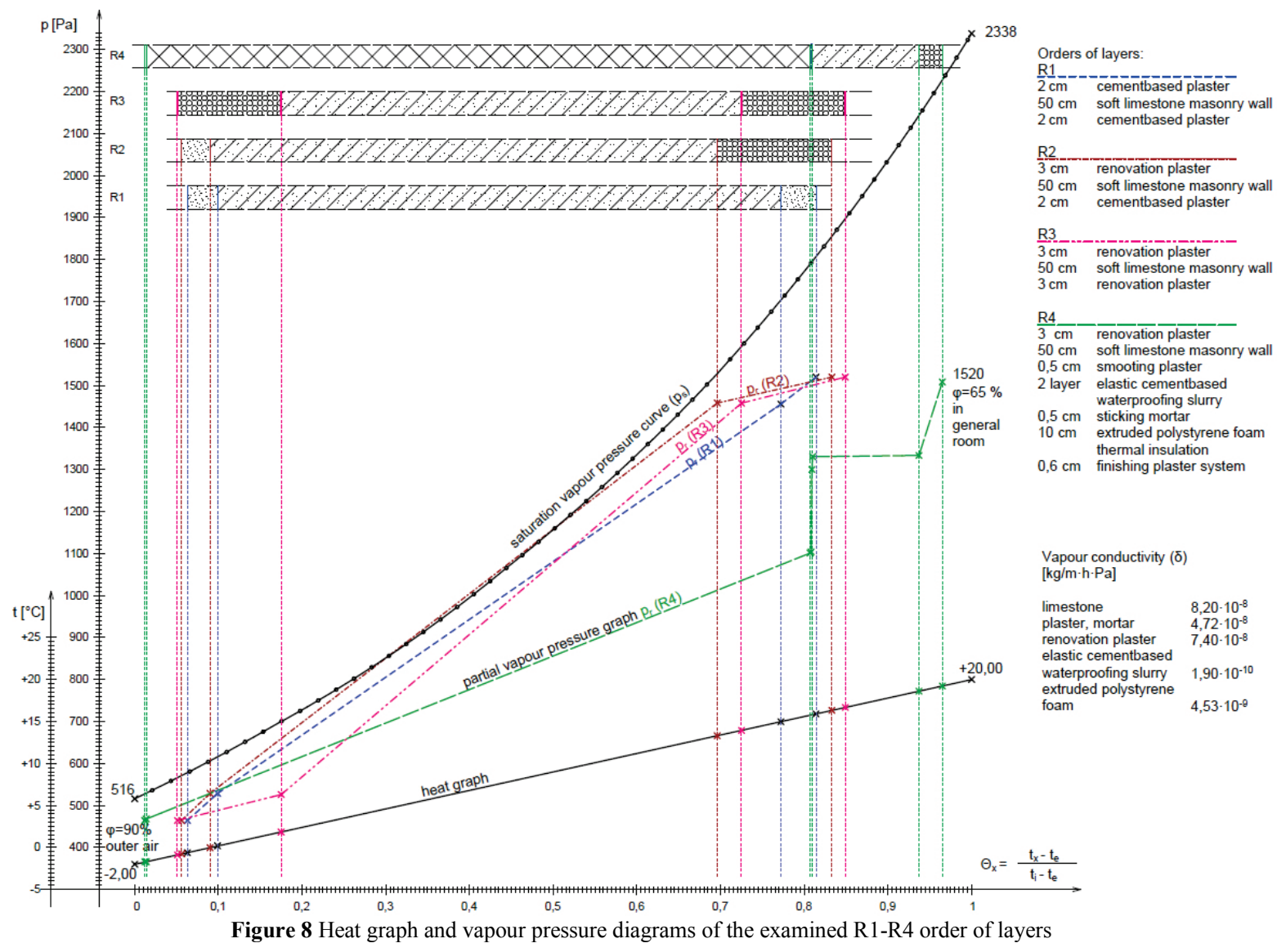

Remaining moisture can escape slowly through an elastic cement mortar insulation coating, and faster through renovation plaster. According to WTA 2-9-04 [29] guideline the material of renovation plaster should have minimum $40 \%$ porosity and maximum $\mu<12$ water vapour resistance factor, hereby it can allow vapour diffusion and storage of remaining salts from evaporation. Restoring plaster considered in the calculation has 
$\delta=7,4 \times 10^{-8} \mathrm{~kg} /(\mathrm{m} \cdot \mathrm{h} \cdot \mathrm{Pa})$ vapour diffusion coefficient $(\mu$ $=9,1$ water vapour resistance factor) and $51,4 \%$ porosity. Vapour conductivity of the elastic cement based waterproofing slurry is $\delta=1,90 \times 10^{-10} \mathrm{~kg} /(\mathrm{m} \cdot \mathrm{h} \cdot \mathrm{Pa})$, which causes high vapour resistance in relation of the whole $\mathrm{R} 4$ order of layers, but compared to oxidized bituminous membranes $\left(\delta=2,01 \times 10^{-11} \mathrm{~kg} /(\mathrm{m} \cdot \mathrm{h} \cdot \mathrm{Pa})\right)$, or to soft PVC $\left(\delta=2,52 \times 10^{-12} \mathrm{~kg} /(\mathrm{m} \cdot \mathrm{h} \cdot \mathrm{Pa})\right)$ it is significantly lower [12, 22].

Fig. 8 shows intersection of pressure graphs only for R2 order of layers, which is the consequence of good thermal insulation capacity of inner restoration plaster. Based on the results it is recommended to apply renovation plaster layers on both sides of a restored masonry in all cases when no thermal insulation system added. Renovation plaster on both sides increases the effective lifespan of the reconstruction. It is also clearly visible that thermal insulation protection of XPS leads to relatively high temperature range on the outer surface of masonry wall, which is an advantage respecting hygrothermal phenomena. At the same time, vapour diffusion transmittance of XPS is low, compared to other materials, as it is visible from slope of graph of R4 order of layers, so it is a disadvantageous material from hygrothermal point of view. At the same time it is observed that the vapour barrier effect of waterproofing slurry is less than the effect of thermal insulation in the examined order of layer.

\section{Summary}

Based on studies described in this article the effectiveness of chemical injection technology as posterior waterproofing solution was verified to retrofit limestone masonry buildings damaged by moisture. Measured average moisture content decreased 43,18\% right above the injection zone, while $H=0,75 \mathrm{~m}$ above it was $56,08 \%$ lower than the saturated moisture content at the examined part of the wall. Effectiveness of reconstruction against moisture could be enhanced with additional waterproofing slurry coatings and renovation plaster layers. The overall posterior waterproofing system not only prevents moisture entering into structural elements and facilitates the departure of residual moisture but also improves thermal performance of the building structure. The results of the simulation model proved that in case of applying waterproofing reconstruction and thermal insulation together significant heat flow decrease can be achieved. At the same time special attention should be paid to reducing thermal bridge effects at the skirting with the application of additional thermal insulations.

Regarding hygrothermal aspects of different reconstruction solutions renovation plasters and waterproofing slurry can be valued higher than other waterproofing materials. The founding of the research again emphasised the importance of precursory hygrothermal examinations, before selecting between reconstruction system components, their order on the structure and choosing techniques applied in parallel.

In conclusion, it was found that moist masonry walls could be efficiently renovated by combined posterior waterproofing systems. In reconstruction complex application of the examined methods can provide healthy conditions with moisture prevented structures.

\section{Acknowledgements}

The authors wish to thank László Farkas for ordering simulation files and predrawing of figures; István Deák and the staff of Aquaseal Ltd. for helping in technical part of the research; my colleagues at the BME, Dr. Valéria Horn and Dr. Ilona H. Baráti for reviewing of the manuscript; Katalin Kopecskó for laboratory measuring; Róbert Garay and Deák Viktor for English language reviewing and Szabolcs Kotek for technical help.

\section{References}

[1] Széll, M. et al. Fenntartható Energetika az épületszerkezetek tervezésében és oktatásában (Sustainable energetics in design and education of building construction) Monograph, Terc Ltd. Budapest, 2012, pp. 131, 125, 142, 148.

[2] Kovacic, I.; Summer, M.; Achammer, C. Life-cycle Oriented Renovation Strategies for Social Housing Stock // Organization, Technology and Management in Construction. 5, 2(2013), pp. 881-891. DOI: 10.5592/otmcj.2013.2.7

[3] Hanák, T.; Vukomanović, M.; Radujković, M. Economic Evaluation of Energy-saving Measures on Panel Building in the Czech Republic. // Tehnicki vjesnik-Technical Gazette 20, 3(2013), pp. 497-504.

[4] Kim, K. P.; Park, K. S. BIM Feasibility Study for Housing Refurbishment Projects in the UK. // Organization, Technology and Management in Construction. 6, 2(2013), pp.765-774.

[5] H. Baráti, I. Egészséges épületek, egészséges irodák: Szárazépítés (Healthy buildings, healthy offices: Dry construction) Presentment in conference Ground plan designer day, Budapest, 10.06.2010, www.met.bme.hu (15.06.2013).

[6] Information on URL: http://www.nachi.org/lifeexpectancy.htm (12.11. 2013).

[7] Möller, K. Vízszigetelés (Waterproofing). Royal Hungarian University Press, Budapest, 1940.

[8] Török, Á. Mészkő műemlékek kőanyagának mállása (Weathering of stone material of limestone historic buildings). Doctoral thesis work for Hungarian Academy of Sciences, 2011.

[9] Juhász P., Kopecskó K. Consolidating and strengthening effect of biomineralization on porous materials. // Concrete Structures. 13, (2012), pp. 65-71.

[10] Künzel H M. Simultaneous Heat and Moisture Transport in Building Components, Fraunhofer Institute of Building Physics, Verlag Stuttgart, 1995, pp. 26-8. URL: http://www.ibp.fraunhofer.de/content/dam/ibp/en/document s/Publikationen/Dissertationen/hk_dissertation_etcm 45 30731.pdf (02.11. 2013).

[11] Fekete I, editor, Épületfizika kézikönyv (Building Physics Handbook). Technical Publisher, Budapest, 1985.

[12] Valtinyi, D. Páradiffúzió praktikum (Hydrothermal characteristics - practicum). 2011, URL: www.met.bme.hu (12.11. 2013)

[13] Pavlikova M., Pavlik Z, Keppert M, Černý R. Salt transport and storage parameters of renovation plasters and their possible effects on restored buildings' walls. // Construction and Building Materials. 25, (2011), pp. 1205-1212. DOI: 10.1016/j.conbuildmat.2010.09.034

[14] Maravelaki-Kalaitzaki, P. Hydraulic lime mortars with siloxane for waterproofing historic masonry. // Cement and 
Concrete Research. 37, (2007), pp. 283-290. DOI: 10.1016/j.cemconres.2006.11.007

[15] Lanzón, M.; García-Ruiz, P. A. Evaluation of capillary water absorption in rendering mortars made with powdered waterproofing additives. // Construction and Building Materials. 23, (2009), pp. 3287-3291. DOl: 10.1016/j.conbuildmat.2009.05.002

[16] Lubelli, B.; van Hees R. P. J.; Hacquebord, A. Experimental study of the distribution of chemical products against rising damp in substrates with different water saturation degrees. // Construction and Building Materials. 40, (2013), pp. 891-898. DOl: 10.1016/j.conbuildmat.2012.11.062

[17] Stefania, I. Chemical waterproofing of the interior walls and buildings front sides. // Constanta Maritime University's Annals. XIII, 18(2012), pp. 123-126.

[18] Bošnjak-Klečina, M; Lozančić, S. Testing of Physical and mechanical Properties of Bricks and Mortar in Historic Structures. // Tehnicki vjesnik-Technical Gazette. 17, 2(2010), pp. 209-215.

[19] Molnár S, editor, Faipari kézikönyv (Forest industry handbook) Forest Industry Scientific Foundation, Sopron, 2000 , pp. $78-79$.

[20] Vergleich der Gleichgewichtswerte in \% mc (Feuchtegehalt) URL: http://www.protimeter.de/ holzfeuchte-aequivalent.html (10.11.2013).

[21] ÉMISZ 340:1999 Standard. Analysis of moist masonries.

[22] Technical documentation. $7^{\text {th }}$ ed. Detmold Schomburg GmbH \& Co. KG. 2013. URL: http://www.schomburg.de/ cmspdf/--5238364-en.pdf (10.11.2013).

[23] International Association for Science and Technology for Building Maintenance and Monument Preservation. WTA 4-4-04/D Guideline, Injection of Masonry in order to avoid capillary moisture content. URL: http://www.wta.de/de/ system/files/4-4-04.pdf .

[24] MSZ EN 12524:2000, Standard, Building materials and products. Hygrothermal properties. Tabulated design values.

[25] MSZ-04-140-2:1991, Standard, Hungarian standard for calculation of hygrothermal properties.

[26] MSZ EN ISO 13788, Standard, Hygrothermal performance of building components and building elements. Internal surface temperature to avoid critical surface humidity and interstitial condensation. Calculation methods.

[27] Moradias, P. A.; Silva, P. D.; Castro-Gomes J. P.; Salazar, M. V.; Pires, L. Experimental study on hygrothermal behaviour of retrofit solutions applied to old building walls. // Construction and Building Materials. 35, (2012), pp. 864873. DOI: 10.1016/j.conbuildmat.2012.04.138

[28] Künzel, H. M.; Holm, A.; Zirkelbach, D.; Karagiozis, A. N. Simulation of indoor temperature and humidity conditions including hygrothermal interactions with the building envelope. // Solar Energy. 78, (2005), pp. 554-561. DOI: 10.1016/j.solener.2004.03.002

[29] International Association for Science and Technology for Building Maintenance and Monument Preservation. WTA 2-9-04 Guideline, Renovation mortar systems URL: http://www.wta.de/cs/system/files/2-9-04.pdf.

\section{Authors' addresses}

Annamária Dudás, Ph.D., M.Sc. civ. eng., Assistant Professor Budapest University of Technology and Economics, Department of Architectural Engineering, 3 Müegyetem rkp, H-1111, Budapest, Hungary Tel: +36 (1) 463-2373, E-mail: dudas.annamaria@met.bme.hu

Anita Terjék, M.Sc. civ. eng., Ph.D-student, Test Engineer Company for Quality Control and Innovation in Building Construction

37 Diószegi str., H-1113, Budapest, Hungary

Tel: +36 (1) 372-6544, E-mail: aterjek@emi.hu 